\title{
Flood Damages Reduction with Evacuation Plans: Life Safety Model implementation on an Italian Basin
}

\author{
$\underline{\text { S. Frongia }}{ }^{\text {a }}$ and Giovanni M. Sechi ${ }^{\text {a }}$ \\ ${ }^{a}$ DICAAR Dept. of Civil and Environmental Engineering and Architecture - University of Cagliari - Italy \\ Email: frongiasara@,tiscali.it
}

\begin{abstract}
Results of tsunami, earthquake, floods and other natural disasters require a deepened preparedness of population tackling with these natural calamities. Specifically, the analysis of flood-events development and resulting effects highlight the inadequacy of people awareness and preparedness in dealing with this kind of risk. Stakeholders and local authorities are facing these challenges taking into account the increase in urbanization, road networks and human activities expansion in flood-prone areas and consequent sprawl of lifelines risk. Recent researches and studies show that the need of specific flood emergency plans implementation is requested by countries to be get a better preparedness managing population evacuation in affected territory.
\end{abstract}

A first phase in the achievement of flood emergency plans is given by defining flood hazard and risk maps in the flood-prone territory, identifying which part of the territory could be mainly involved and the related hydraulic values consequent to flood flows.

This paper describes a modelling approach to manage the evacuation process in case of flood emergency: the research has been pursued using the software Life Safety Model (LSM, (BC Hydro, 2006)). The flood event development in the territory is described in terms of time and space expansion occurrences, allowing LSM to get a feasible description of receptors reactions when the flood occurs. LSM produces baseline data to support population and territory management in case of emergency, reducing and, possibly, avoiding loss of lives which is contemplated as the worst potential damage.

The project presented herein studies the applicability of LSM to the Coghinas River lowland valley basin: this has been considered as the pilot basin in the Regional Flood Risk Management Plan for Sardinia, Italy. The study collects information about each receptor located in the area: population (residents and tourists), buildings and infrastructure networks. LSM is developed considering the 2D hydraulic model RFSM-EDA (HR Wallingford Ltd, 2013) in order to describe a flood event of 200 years return period in terms of water depth and velocity evaluation. Flood-event features description on the territory allows LSM to model its evolution, to evaluate potential damages and to easily show, by a visual interface, the emergency development. A proper and detailed representation of the urban network criticalities and social environment during the event should be a safeguard from reaching greater damages: the event simulation verifies the effects of alert/evacuation warnings, as well as activating proper safety actions mainly on crucial points at high level of risk.

Keywords: Emergency plans, flood risk reduction, Life Safety Model, flood damages prevention 
Frongia and Sechi, Flood Damages Reduction with Evacuation Plans: Life Safety Model implementation on an Italian Basin

\section{INTRODUCTION}

Climate change increases the unpredictability of flood events, leading the monitoring organisation of European countries to improve their Flood Risk Management Plan and manage vulnerable territory, reducing adverse consequences in case of floods. In addition to climate change, the current trend of people moving from rural areas to cities increases urbanization and, as a consequence, an emergency or disaster management plan is necessary in terms of preparation, support and reconstruction when natural or man-made disasters occur (Price and Vojinovic, 2008).

Flood events that occurred in Sardinia (Italy) caused relevant damages to properties, infrastructures and even victims and injuries. The analysis of post-event conditions are required to work deeply forecasting flood development and modelling evacuation plans of action, assuring the awareness of flood risk and limiting life losses. The DICAAR Research Team of the University of Cagliari is working to support the Sardinian Hydrographic District Authority and the Civil Protection Agency on improving the Sardinian Flood Risk Management Plan (FRMP). In detail, floodplain maps and scenarios of structural mitigation measures were provided. They are the bases to identify the level of flood risk using them as instruments not just for defining and communicating flood risks, but mainly, to regulate territory uses by rationalising the inevitable limits and failures of controls, providing awareness of the potential floodplain area (Demeritt and Porte, 2012). The resulting flood maps are the launch pads to assess and give an order of the magnitude of the flood consequences (Frongia et al., 2015a). In contrast with engineered defences designed to keep water away, it is important to understand potential consequences and help communities and authorities to become more resilient and adapt to changing levels of flood risks (Demeritt and Porte, 2012).

This work aims to supply rules for the flood emergency management and for the coordination phase of the population when they have to evacuate promptly and safely toward safe havens. That aspect led to focus the attention of the project on loss of lives prevention considered by the majority of the researchers as direct intangible damage in the flood damage categorisation (MCM Model, 2005).

Simulation and results of potential evacuation actions have been implemented in the area of the pilot basin of the Sardinian FRMP: the Coghinas river lowland valley basin, shown in Figure 1. Building, population and territory features of the pilot basin have been collected and organised in databases. Later the territory has been studied with the HR Wallingford 2D hydraulic model RFSM-EDA set with boundary conditions and flow data given by the Sardinian Fluvial Zones Definition Plan (PSFF) to simulate the flood inundation (RAS, 2013) (HR Wallingford Ltd, 2013). The 2D model allows to observe flow intensity development and, in particular, water depths and velocity value increments, assessing the damages and giving recommendation

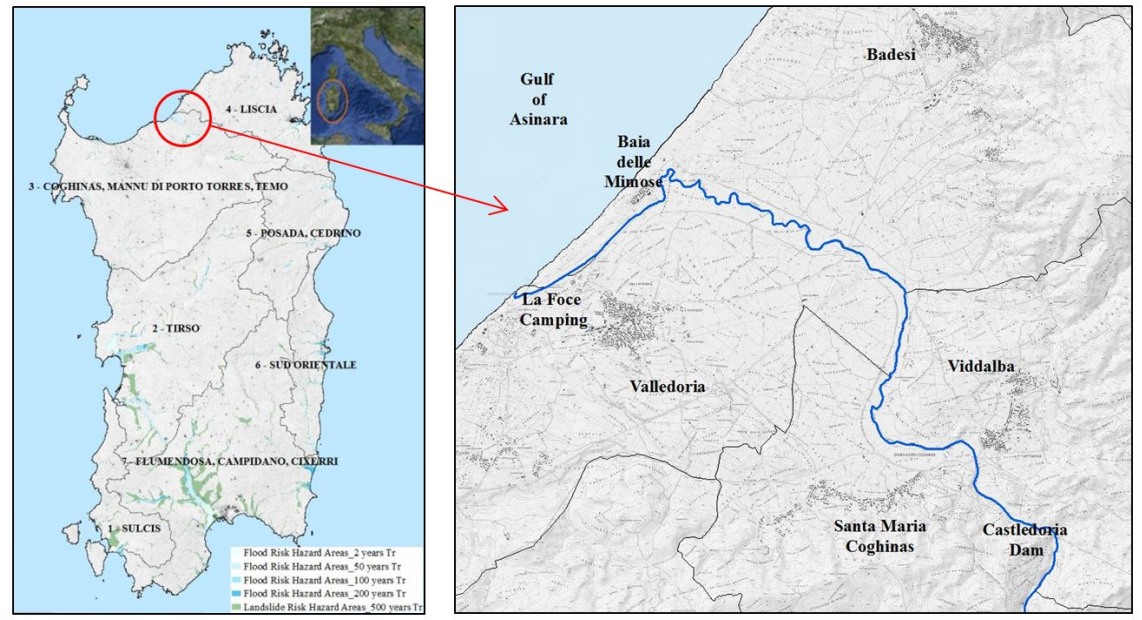

Figure 1. Sardinian hydrographic basins, PSFF flood hazard maps and localization of the case study in Italy (left side) (Frongia, 2017); Coghinas River lowland valley basin and council boundaries (right side) for evacuation plan predisposition with the Life Safety Model (LSM (HR Wallingford Ltd, 2015)). LSM is a dynamic agent-based model that assesses receptors behaviour when they interact with flood flow intensity and evaluate quantitative damages to building, vehicles and population. The analysis and results of receptor reactions under flood risk allow the user to identify evacuation actions such as when to send the warning and evacuation issuances, where to line up forces to manage the road network, from where to disseminate the flood alert to notify at all of the population the risk, and other possible actions aiming to improve emergency planning (BC Hydro, 2006). LSM results are significant to observe changes, to reduce loss of lives and to simulate the scenario under analysis identifying where the victims may occur and when should be better to act preventing them. 
Frongia and Sechi, Flood Damages Reduction with Evacuation Plans: Life Safety Model implementation on an Italian Basin

\section{THE STUDY CASE: COGHINAS RIVER LOWLAND VALLEY BASIN}

The case study considered the pilot basin of the Sardinian FRMP located in the North coast of the territory as part of the sub-basin n. 3 in the Sardinian hydrographic district basin categorisation (see Figure 2). The Coghinas River lowland valley basin was hydraulically analysed to identify which part of the area could be under flood hazard for events with probability of occurrence of 2, 50, 100 and 200 years as defined in the Sardinian PSFF (polygons with blue shades in the Figure 1) and recently re-analysed for the last three return periods events (Frongia et al., 2015a). The Coghinas River drains a $2453 \mathrm{~km}^{2}$ catchment along $115 \mathrm{~km}$. It is regulated by two dams, Muzzone and Casteldoria dams. The Muzzone reservoir is located in the upstream of the Coghinas River, while the Casteldoria reservoir is at $15.9 \mathrm{~km}$ from the river mouth before emerging in the Gulf of Asinara. The lower part of the Coghinas River, from the Casteldoria dam to the outlet, is the area under analysis. The territory is managed by four council regions: Viddalba, Santa Maria Coghinas, Valledoria and Badesi. Information was collected about the spatial distribution of the habitable buildings and the residential and tourist component of the population in the area potentially flooded.

\subsection{RFSM-EDA floodplain}

The study herein developed required the predisposition of two-dimensional hydraulic models to identify the flow intensity values at each step of the flood progression and, therefore, the values of water depths and velocities in each point of the area under risk. Following the simulation, it is possible to know how the floodwater interacts with the structure mitigation measure (mainly levees) and identify weak points caused by possible failures or inadequacy of the structures to contain the water. The hydraulic model has been obtained implementing RFSM-EDA and setting it with the boundary conditions defined in the Sardinian FRMP to compare and validate the results for the events of 50, 100 and 200 years.

RFSM-EDA is a computational engine made available by HR Wallingford Ltd for the simulation of inundations. It is able to provide water depth and velocity outputs with short simulation runtimes (HR

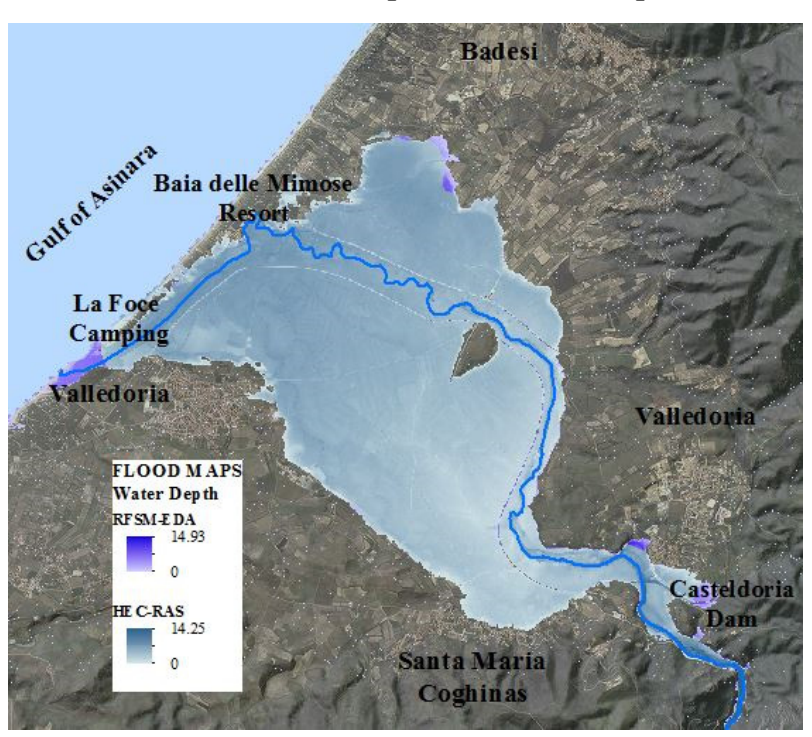

Figure 2. Comparison of the RFSM-EDA and HECRAS maximum water depth value maps Wallingford Ltd, 2013). The event characterised by a probability of occurrence of 200 years is herein shown. The upstream boundary conditions are set at the level of the Casteldoria dam from where a water flow rate is discharged considering a hydrograph schematised with triangular shape. The event reaches the maximum flow discharge rate of $4460 \mathrm{~m}^{3} / \mathrm{s}$ at 9.9 hours, while the downstream boundary conditions consider a free water surface of 1.8 metres above the standard sea level. Moreover, Manning roughness coefficient of the riverbed and adjacent area have been uploaded (Frongia et al., 2015a). RFSMEDA 2D flood map confirmed the results of the Sardinian FRMP obtained previously running the 1D HEC-RAS model. In fact, the floodplain extents and the maximum water depths obtained from the two methods are quite similar. HECRAS estimates a water depth range between 0 and 14.25 metres, while RFSM-EDA water depth values are between 0 and 14.93 metres, as shown in Figure 2. RFSM-EDA model shows the capacity of the levees to contain the flood for the first 2.5 hours of the event. Gradually after 3 hours the right river bank starts to overflow, while the agricultural areas beyond the right embankment are at the beginning of the inundation. The simulation shows relevant damages at 3.5 hours in the left river bank especially in the La Foce Camping area and the suburban area of Valledoria town. Finally, at 5 hours the Baia delle Mimose Resort area is flooded. The analysis underlines that the study area could already be damaged even before the flood reaches the peak of the event.

\subsection{Receptors distribution: building and population}

The urbanised areas of Valledoria, Santa Maria Coghinas, Viddalba and Badesi consist of different types of building structures including dwellings, public offices, commercial, industrial and tourist buildings. The territory required a deep analysis and collection of data in terms of population distribution. 
Frongia and Sechi, Flood Damages Reduction with Evacuation Plans: Life Safety Model implementation on an Italian Basin

Viddalba town consists of 822 buildings able to be populated by 1726 residents and 16 tourists. The Santa Maria Coghinas town is defined by 700 structures populated by 1436 residents while the tourist population could reach a maximum of 245 .

The Badesi town is located outside the potential floodplain risk area, but it manages the resort area of Baia delle Mimose built near the mouth of the Coghinas River on the right-hand side of the river. The resort itself could host 1521 tourists in 317 accommodation units. According with the Alert Operating Instructions of the Sardinian Civil Protection Agency, 74 resort buildings in the suburban area of the Badesi town could be taken under consideration as potential shelters for flood emergency evacuation because they are located sufficiently away from the flood risk area (RAS, 2014). Valledoria town consists of 1051 structures hosting 3223 people between residents and tourists. A second part of the tourist population in the Valledoria area could be accommodated in the La Foce camping area, located near the mouth of the Coghinas River on the left-hand side. This area is of particular interest for the study case because of its vulnerable location: La Foce consists of 408 vulnerable structures, tents, mobile homes, campers and bungalows, where 1204 tourists could sojourn. A complete analysis of the studied area shows a total of 3372 buildings distributed in the area that could host a maximum number of 9371 people between residents and tourists. The population amount has been increased to 9450 aiming to take into account uncertainties in collecting data and demographic increments.

\section{LIFE SAFETY MODEL IMPLEMENTATION ON THE STUDY CASE}

\subsection{Overview and structure of LSM}

Recent major flood events around the world have highlighted the importance of an effective emergency response in minimising loss of life and optimising the resources available (Lumbroso et al., 2011). Evacuation modelling can predict "bottlenecks" in the system before they are experienced, it can also be used to determine the impact of road closure due to flooding and the impact of phased evacuation scenarios can lead to establishment of appropriate evacuation policies and shelter strategies.

LSM is able to model a flood evacuation event relating a 2D hydraulic model with a virtual world representative of the area under analysis characterised by elements called receptors (Frongia and Sechi, 2016a). This agent-based model is the result of the implementation of research focused on the analysis of buildings, vehicles and people instability when hit by flood. The model uses generalised event logic to determine the location of each receptor, whether it is aware of the flood wave, if it is trying to find a safe haven, what happens if it encounters the flood and whether the object survives or not (Tagg et al., 2016). Loss functions characterise the model assessing how receptors behave when they interact with water depth and velocity values. These loss functions require to be set with parameters representative of the receptors physical characteristics and boundary of resistance. In particular, people parameters are described in terms of their ability to escape the flood risk by driving, walking or releasing themselves in order to avoid drowning or decline of health due to immersion in cold water, as described in Figure 3 (BC Hydro, 2006).

LSM requires the description of the population in terms of individuals and group of people. These receptors are located in the area, and considering the time when the event is analysed their location could change between dwellings and the work place. Evacuation modeling requires a detailed description of the road network to

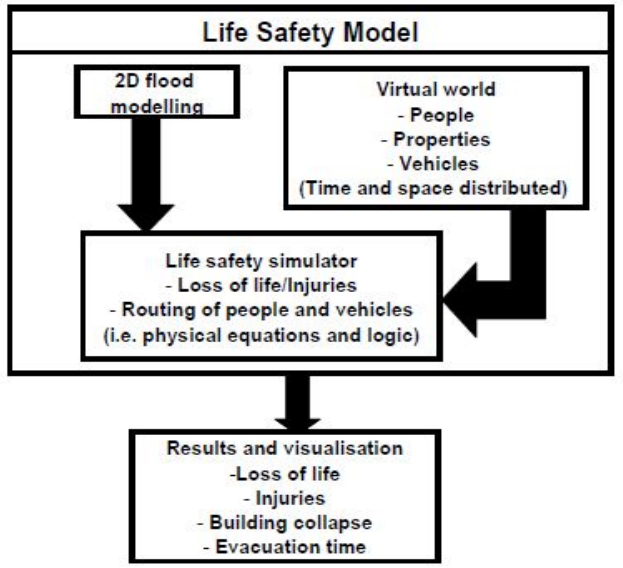

Figure 3. High-level architecture of the Life Safety Model (Lumbroso and Di Mauro, 2008) (BC Hydro, 2006) allow people and vehicle movements toward safe havens. Emergency plan actions could be modelled as when to disseminate the flood alert and when to send the evacuation issuance.

\subsection{Evacuation Plan and Loss of Lives Analysis}

The LSM virtual world of the pilot basin is described by Building, individuals (PARU), group of people (PARG) and Vehicle defined concurrently with the Road Network in order to pinpoint the evacuation path preferable during the emergency situation. LSM is set with Warning Centres that are points in the area from where the evacuation warning should be sent, and it is possible to define the lapse among the pre-alert, when the signal is sent and when the signal is received by receptors. Three main warnings manage the study case: 
Frongia and Sechi, Flood Damages Reduction with Evacuation Plans: Life Safety Model implementation on an Italian Basin

the management office of Casteldoria dam, and the council buildings of Viddalba and Valledoria towns. Moreover, LSM describes management actions, called Events, that represent the potential mitigation measures feasible by the Civil Protection Authorities and rescuers to reduce risks and weakening exposure to hazards. The possible events include the closure of roads and bridges around or within the floodplain area considering that they are weak points difficult to be managed by the authorities during the emergency. The Coghinas River lowland valley basin model has been set to have a uniform distribution of resident people in dwellings, while the La Foce camping and Baia delle Mimose resort, as tourist areas, are considered fully booked.

Firstly, the model has been run for three scenarios. The No Warning scenario considers people starting to evacuate when they realize a flood is occurring and water depths are around 0.20 meters. The second scenario sends the warning when the event starts and the third scenario couples the second scenario with the closure of bridges in critical points of the area. The models have been run a number of times looking for the best results given especially by a prompt evacuation warning and an accurate definition of shelters in the area (Frongia et al., 2016b). Shelters consisting of tourist buildings, hotels, resorts or particular dwellings able to host people are identified in terms of host capacity, in fact LSM showed a large death toll when shelters were not able to host all of the people and those who were refused entry had to move away to other shelters, risking to be drowned by the flood.

The three scenario results show that the victims occurrence could be completely avoided by managing properly the evacuation issuance, assuring them enough time to reach safe havens. The No Warning scenario evaluates 806 victims, $8.53 \%$ of the population in the area; while by sending the evacuation issuance at the beginning of the event all of the population are prepared and reaches shelters safely. PARG and Vehicles results follow the same behaviour of PARU conditions. Building states do not change because they are not influenced when the evacuation mitigation measure are activated.

Then, the model has been improved by considering only the evacuation of

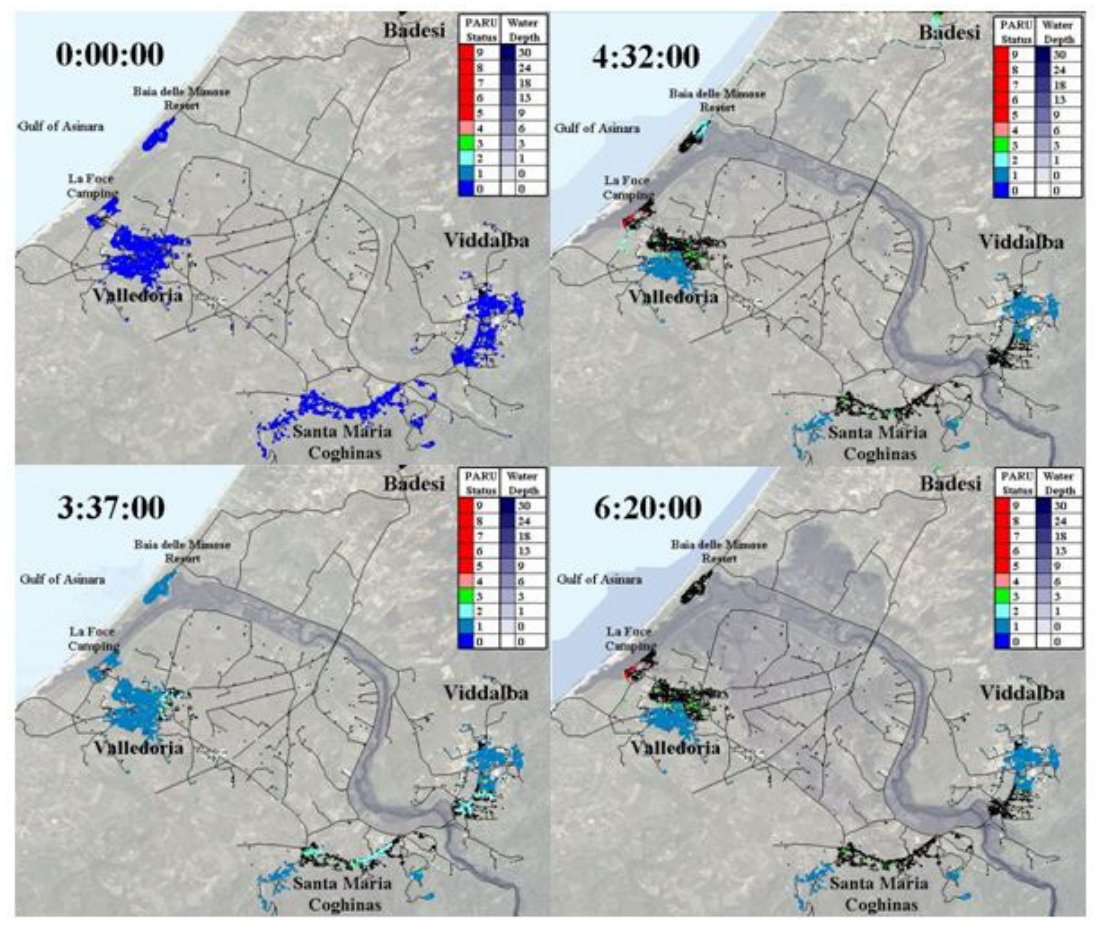

Figure 4. Extract steps of the floodplain development for the case study baseline scenario with the evacuation issuance sent at 6 hours from the peak of the event dwellers and tourists within 500 meters from the floodplain boundaries. It was re-run a few more times, increasing gradually the flood evacuation signal with delays of 20 minutes until the event reaches 10 hours of development. In particular the attention was given on the scenario characterised by an evacuation issuance sent at 6 hours from the peak of the event when the first fatalities are registered. Figure 4 shows the steps of evacuation scenario development aiming to represent the most significant steps on the receptors' behaviour, especially for the analysis of the population. The PARU states changes gradually from blue shades to green or red colour, respectively to those in safe conditions hiding in shelters and to those who became victims (drowned, exhaustion, building collapse, drowned in building and vehicle toppled).

Let us now shift our attention on people reactions and post-event conditions. International studies show that generally a human starts to lose physical stability at around 0.30 metres of water depth, but mobility is still allowed until a water depth around the chest, more or less the $70 \%$ of the person's height (Lumbroso and Tagg, 2011). Their reaction has been studied by testing results in case of adult, children or elderly, but also observing body reaction to different temperatures of the water, especially under cold water conditions. LSM relates the water depth and velocity values with the receptors' strength parameters at each time step, simulating the potential behaviour of each receptor when hit by the flood wave: if they could stand or could 
Frongia and Sechi, Flood Damages Reduction with Evacuation Plans: Life Safety Model implementation on an Italian Basin

be overcome by the flowing water (Cox et al., 2004)(Engineers Australia, 2012) (Hayward et al., 1975)(Keller and Mitsch, 1992)(Penning-Rowsell et al., 2005).

Figure 5 compares results of fatalities assessed by LSM when the evacuation issuance is sent with delays of 20 minutes starting at the beginning of the event until 1 hour from when the event reaches the maximum discharged flow. The No Warning scenario registered 806 victims and it is represented in the "Number of fatalities" axes for convenicence to be compared with the other scenario results. Observing the chart, there is

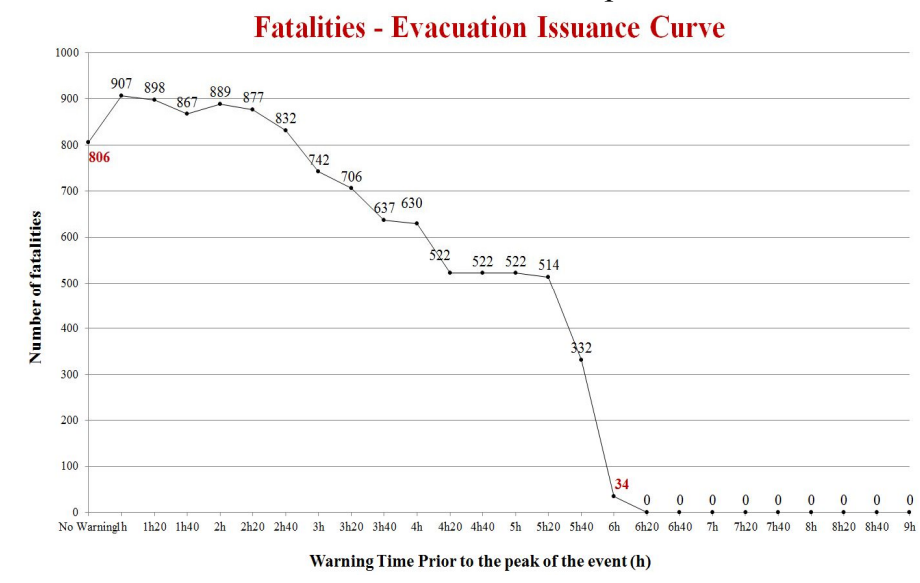

Figure 5. Death Toll Evaluation in the Coghinas river lowland valley basin for scenarios with different flood evacuation issuance victims. a gradual decrease in the number of fatalities by improving the time between the flood evacuation issuance and the arrival of the flood wave peak (reasing the chart from tthe right side to the left side). In fact the number of fatalities is reduced to 34 (registered mainly in the touristic area near the mouth of the river) if the evacuation issuance is set at 6 hours prior to the peak of the event, and it is eliminated if the warning is issued 6 hours and 20 minutes prior to the peak of the event. In summary just a 20-minute delay sending the evacuation issuance could be critical in preventing the occurrence of

\section{DISCUSSION AND CONCLUSIONS}

LSM software offers useful outputs for the evaluation of residual flood risk and the assessment of the flood consequences in terms of potential damage. The properties and results shown in the present paper aim to fulfil the requirement of Flood Directive 2007/60 in supporting the Flood Risk Management Plans development. The continuous improvement of the FRMPs leads every Hydrographic Basin authority to fulfil the planned mitigation measures and provide new methodologies to prevent losses caused by residual risks.

Flood events occurred in Sardinia (Italy) underline that part of the economic damages and the death toll could be avoided by activating with appropriate emergency actions. This observation underlines the necessity to improve social preparedness with the aid of proper flood management plans to identify how people should behave as required in Article 7 of Flood Directive 2007/60.

The building states analysis shows no performance changes in improving emergency management because building resistance could change only by modifying resistance to water depth and velocities with structural mitigation measures or, at least, using temporary flood intensity protection measures such as sand bags, water-resistant external windows and/or doors, water-resisting air bricks/permanent air brick covers, etc. The developed analysis explains that, from the three scenarios analysed beforehand, vehicle losses can decrease by improving the lead time of issuing warnings so that people will have more time to reach a safe haven and also reduce potential goods loss along the road network. Life loss values, however, are prioritized for their intangible damage evaluation. The fatalities-evacuation issuance curve shows changes on the number of victims in direct relation to the time the evacuation order is sent and disseminated to the population. Observing the curve and underlining its specificity for the case study, it is possible to observe how victimization could be avoided by managing properly the emergency and evacuation phases during floods. Moreover, the curve highlights that it should be better to issue the evacuation order way before the simulated peak of the flow wave to prevent more damages and victims, being certain that the inhabitants are sheltered in their or a friend's dwelling or, if absolutely needed, in proper safe havens.

\section{ACKNOWLEDGMENTS}

Sara Frongia gratefully acknowledges the Sardinia Regional Government for the financial support of her PhD scholarship (P.O.R. Sardegna F.S.E. Operational Programme of the Autonomous Region of Sardinia, European Social Fund 2007-2013 - Axis IV Human Resources, Objective 1.3, Line of Activity 1.3.1.). The achievement of these results has been gained thanks to the collaboration of the Flood Department of HR Wallingford Ltd. 
Frongia and Sechi, Flood Damages Reduction with Evacuation Plans: Life Safety Model implementation on an Italian Basin

\section{REFERENCES}

BC Hydro (2006). BC Hydro Life Safety Model System V1.0- Guidelines, Procedures, Calibration and Support Model.

Civil Protection-RAS (2014). Alert Operating Instructions for the Civil Protection (Manuale operativo delle allerte ai fini della protezione civile).

Cox R.J., Yee M. and Ball J.E. (2004). Safety of People in Flooded Streets and Floodways. $8^{\text {th }}$ National Conference on Hydraulics in Water Engineering, Gold Coast.Australia: The Institution of Engineers.

Demeritt D. and Porter J. (2012). Flood-risk management, mapping, and planning: the istitutional politics of decision support in England. Environment and Planning, 2359-2378.

Di Mauro M., De Bruijn K.M., Meloni M. (2012). Quantitative methods for estimating flood fatalities: towards the introduction of loss-of.life estimation in the assessment of flood risk. Natural Hazards, 10831113.

Engineers Australia (2012). ARR Project 10 People and Vehicle Stability. Australian Rainfall and Runoff-A guide to runoff estimation.

European Commission (23 October 2007). EU Directive 2007/60 on the Assessment and management of flood risks. Official Journal of the European Union.

Frongia S. (2017). Economic evaluation of flood damages and identification of priorities defining mitigation measures actions.

Frongia S., Melis M., Sechi G.M. and Silvano R.(2015a). Flood Risk Management Plan for the Sardinia Hydrographic District. European Water Resources Association. Istanbul.

Frongia S. and Sechi G.M. (2016a). Flood Evacuation Plan As Support For Flood Disasters Management. AMBIENTE, RISORSE, ENERGIA: LE SFIDE DELL'INGEGNERIA DELLE ACQUE IN UN MONDO CHE CAMBIA, p. 891-894. Bologna.

Frongia S., Sechi G.M. and Davison M.(2016b). Tangible and Intangible Flood damage evaluation. $3^{\text {rd }}$ European Conference on Flood Risk Management. Lyon.

Hayward J.S., Eckerson J.D., Collis M.L.(1975). Thermal Balance and Survival Time Prediction of Man in Cold Water. Canadian Journal of Physiology and Pharmacology, 21-32.

HR Wallingford Ltd (2013). Guidance for the use of RFSM_EDA and AccData.

Jonkman S.N. and Penning-Roswell E. (2008). Human Instability in flood flows. Journal of the American Water Resources Association, 1-11.

Keller R.J. and Mitsch B.F. (1992). Stability of Cars and Children in Flooded Streets. International Symposium on Urban Stormwater Management, Sidney, p. 264-268.

Lind N. and Hartford D. (2000). Probability of human instability in a flooding: A hydrodynamic model. Proceedings Applications of statistics and probability. Rotterdam: Melcher, R.E.; Stewart, M.G.

Lumbroso D. and Di Mauro M. (2008). Recent developments in loss of life and evacuation modelling for flood event management in the UK. International Conference on Flood Recovery, Innovation and Response (FRIAR).

Lumbroso D., Johnstone W., De Bruijn K., Di Mauro M., Lence B. and Tagg A.(2010). Modelling Mass Evacuations to improve the emergency planning for floods in the UK, The Netherlands and North America. International Conference on Emergency Preparedness (InterCEPt), the Challenges of Mass Evacuation. Birmingham.

Lumbroso D.M. and Tagg A.F.(2011). Evacuation and loss of life modelling to enhance emergency response. International Symposium on Urban Flood Risk Management. Graz.

Needham J., Fields W. and Lehman W. (2016b). The US Army Corps of Engineers Scalable Approach to Estimating Loss of Life from Flooding. $3^{\text {rd }}$ European Conference on Flood Risk Management. Lyon

Penning-Rowsell, E.C., Floyd P. , Ramsbottom D. , and Surendran S. (2005). Estimating Injury and Loss of Life in Floods: A Deterministic Framework. Natural Hazards 36, 43-64.

Price R.K. and Vojinovic Z. (2008, September ). Urban flood disaster management. Urban Water Journal, 5(3), 259-276.

Ramsbottom D., Wade S., Floyd P.,Penning-Rowsell E.,Surendran S.(2004). Outputs: Flood Risks to People. Phase 2. FD2321. London, United Kingdom: Department for the Environment, Food and Rural Affair/Environment Agency.

RAS-PSFF (2013). Piano Stralcio Fasce Fluviali (PSFF).

RAS (2014). Progetto di Piano di Gestione del rischio alluvioni (FRMP). Cagliari.

Shand T.D., Smith G.P., Cox R.J. and Blacka M.(2011). Development of Appropriate Criteria for the Safety and Stability of Persons and Vehicles in Floods. $34^{\text {th }}$ IAHR Conference. Brisbane.

Tagg A., Davison M. and Wetton M.(2016). Use of agent-based modelling in emergency management under a range of flood hazards. $3^{\text {rd }}$ European Conference on Flood Risk Management. Lyon 